Article

\title{
Energy Security Assessment of Emerging Economies under Global and Local Challenges
}

\author{
Iryna Sotnyk $^{1}{ }^{\circledR}$, Tetiana Kurbatova ${ }^{2}$, Oleksandr Kubatko ${ }^{1}\left(\mathbb{D}\right.$, Olha Prokopenko $\left.^{3, *} \mathbb{(}\right)$, Gunnar Prause ${ }^{4}(\mathbb{D}$, \\ Yevhen Kovalenko ${ }^{1} \oplus$, Galyna Trypolska ${ }^{5}$ and Uliana Pysmenna ${ }^{5}$ \\ 1 Department of Economics, Entrepreneurship and Business Administration, Sumy State University, \\ 40007 Sumy, Ukraine; sotnyk@econ.sumdu.edu.ua (I.S.); okubatko@econ.sumdu.edu.ua (O.K.); \\ kovalenko@econ.sumdu.edu.ua (Y.K.) \\ 2 International Economic Relations Department, Sumy State University, 40007 Sumy, Ukraine; \\ t.kurbatova@macro.sumdu.edu.ua \\ 3 Department of Economics and International Economic Relations, International Humanitarian University, \\ 65009 Odesa, Ukraine \\ 4 Wismar Business School, Wismar University, 23966 Wismar, Germany; gunnar.prause@hs-wismar.de \\ 5 Department of Sectoral Forecasting and Market Conditions, Institute for Economics and Forecasting, \\ National Academy of Sciences of Ukraine, 01011 Kyiv, Ukraine; g.trypolska@gmail.com (G.T.); \\ uliamyxa@gmail.com (U.P.) \\ * Correspondence: prokopenko.olha.w@gmail.com
}

Citation: Sotnyk, I.; Kurbatova, T.; Kubatko, O.; Prokopenko, O.; Prause, G.; Kovalenko, Y.; Trypolska, G.; Pysmenna, U. Energy Security Assessment of Emerging Economies under Global and Local Challenges. Energies 2021, 14, 5860. https:// doi.org/10.3390/en14185860

Academic Editor: Nuno Carlos Leitão

Received: 3 September 2021

Accepted: 13 September 2021

Published: 16 September 2021

Publisher's Note: MDPI stays neutral with regard to jurisdictional claims in published maps and institutional affiliations.

Copyright: (c) 2021 by the authors. Licensee MDPI, Basel, Switzerland. This article is an open access article distributed under the terms and conditions of the Creative Commons Attribution (CC BY) license (https:// creativecommons.org/licenses/by/ $4.0 /)$.

\begin{abstract}
This paper proposes methodological approaches to assessing the impact of renewable energy and energy efficiency development on emerging economies' energy security. It is suggested to supplement the current methodology for assessing energy security with the decoupling index of the renewable energy financial burden on the state budget, the energy efficiency decoupling index, the households' energy poverty indicator, the index of capacity development for balancing electricity generation volumes, and the energy fluctuations indicator. These indices provide a comprehensive assessment of energy security under the latest challenges. Thus, the COVID-19 pandemic in the Ukrainian energy sector led to the "green and coal paradox", when the government decided to keep green electricity generation but limit nuclear generation. It required increased flexible capacities (thermal generation) and led to a rise in electricity prices and environmental pollution. Forecasting energy fluctuations with Butterworth filters allows minimizing the risks of maximum peak loads on the grid and timely prevention of emergencies. The energy fluctuations within the $20 \%$ range guarantee energy security and optimal energy companies' operation. It is proposed to smooth out energy consumption fluctuations through green energy development, smart grids formation, energy efficiency improvements, and energy capacities balancing to ensure energy and economic sustainability.
\end{abstract}

Keywords: COVID-19; energy efficiency; energy policy; energy security; energy sustainability; emerging economy; fluctuations; renewable energy; Ukraine

\section{Introduction}

Being the basis for national economies' operation, the energy sector is one of the biggest environmental polluters. Considering the current ecological threats and the global community's focus on the Sustainable Development Goals implementation [1], the issues of the energy transition to the use of environmentally friendly renewable energy sources (RES) [2-5], and the energy-efficient technologies [6-8] currently present real challenge.

The promotion of the green energy sector has many ecological (reducing environmental pollution), social (increasing energy services' availability), and political benefits (declining dependence on fossil fuels). However, today, most renewable energy (RE) technologies are immature. Consequently, the cost of green power is higher than the cost of traditional energy. It causes the non-competitiveness of RE technologies in the market. 
Therefore, countries that develop green energy have to provide state support. However, sometimes, economic support schemes may be ineffective and even harmful in the face of the latest global and local challenges, particularly the COVID-19 pandemic. The paradoxical result of this impact is the weakening of energy sustainability and security, coupled with increasing environmental pollution.

According to the Energy Trilemma, defined by the World Energy Council, the key elements of sustainable energy development are closely related to energy security, energy equity, and environmental sustainability [9]. On the one hand, the gradual transition to the RE era increases energy availability for nations and countries, positively affecting energy security and environmental sustainability $[10,11]$. On the other hand, it creates new threats primarily to energy security, which are associated with RE technologies' imperfection, their high capital cost, and the consequential need for state support and following price distortions in the energy market. In addition, RE development may cause overloading of the existing energy infrastructure, threatening rolling blackouts for energy consumers and escalating the need for infrastructure expansion and reconstruction.

In particular, the fragility of the balance between traditional and green power capacities was demonstrated by the spring 2020 crisis in the Ukrainian power industry due to the introduction of stringent COVID-19 quarantine restrictions. These conditions forced the state to limit the generation of cheap electricity by nuclear power plants in favor of expensive green electricity (because the government guaranteed its purchases). Additionally, relatively costly electricity from thermal power plants was supported (due to greater flexibility of their capacities than nuclear power plants) $[12,13]$. This situation has disrupted all components of the energy trilemma since access to energy has been deteriorated due to rising energy prices and energy security reduction. In addition, environmental sustainability has been worsened due to the use of thermal instead of nuclear power plants.

The green energy deployment and the growing RES share in Ukraine's electricity mix change the installed energy capacities distribution, electricity generation structure, and related financial flows. High feed-in tariffs guaranteed by the state stimulates active development of RE power plants with rising green electricity generation, which is mandatory for government procurement [10]. As the Ukrainian Government has not identified special sources of feed-in tariffs' funding, the RE share's growth boosts weighted average electricity prices in the country. Due to this, the financial burden on consumers is constantly growing. The state currently restrains it by forming the deficit at the State Company "Guaranteed Buyer", which at the end of 2020 amounted to 24.6 billion UAH [14]. For instance, in 2017, $1.5 \%$ of the green energy share in the total electricity mix provided $7.5 \%$ of the price burden on the domestic electricity market [15]. In 2020, the share of electricity from RES in Ukraine increased to $8 \%$, which is $26 \%$ of the electricity market's money turnover [16]. It is evident that such a situation may lead to a payment collapse in the energy system, threatens the country's energy security, and needs to adjust the feed-in tariffs.

In addition, the prerequisite for the reduction of feed-in tariffs is the steady trends of cheapening RES technologies, which are observed in global and local markets. In particular, in 2010-2019, the electricity generation costs for solar photovoltaic and onshore wind farms dropped by $82 \%$ and $39 \%$, respectively. Moreover, the electricity costs for more than $50 \%$ of the RE capacities commissioned in 2019 were lower than for fossil fuel power plants [17].

Reducing the cost of generating green electricity is reflected in the gradual decline in government financial support for the RE sector. According to [18], a gradual decrease is provided for the feed-in tariff coefficients, which form the prices for electricity from RES. For example, the feed-in tariff coefficient for electricity generated by solar power plants, whose installed capacity exceeds $10 \mathrm{MW}$, has decreased 1.7 times compared to 2013. For wind energy generated by power plants with a capacity of more than $2 \mathrm{MW}$, the feed-in tariff coefficient has decreased by 1.3 times for the same period. Bioenergy technologies demonstrate a slower rate of decline in the generation cost. Therefore, their feed-in tariff coefficient has decreased by 1.1 times compared to 2013 [19]. 
Due to growing competitiveness, wind energy is becoming an economically attractive solution for the national economy's decarbonization, aligning short-term economic needs with long-term sustainable development goals. However, wind power plants' dynamic deployment faces problems of the infrastructure improvement for green electricity storage and transportation. It requires significant investment for the effective integration of green energy facilities with the United Energy System of Ukraine (UESU). Another issue is the lack of the UESU's flexible capacities, which has become noticeable against the background of dynamic RE development, on the one hand, and the reduction in energy consumption caused by the COVID-19 pandemic, on the other hand. According to the system operator NEC “Ukrenergo", 1.6 GW of energy storage capacity in 2021, 1.8 GW in 2025, and 2 GW in 2030 are required for effective RES integration into the UESU and its safe operation [20].

The experience of this crisis, which continues in Ukraine today, proves the need to develop new approaches to assessing and forecasting the level of energy security of the national economy considering its RE promotion and global and local threats. These issues are also relevant to other transitive countries that are developing green energy under the COVID-19 pandemic. Moreover, they can be applied to emerging oil-based economies with ongoing energy transitions such as Azerbaijan [21,22] and Kazakhstan [23] to estimate their energy security changes under world and domestic fluctuations of fossil fuel and renewable energy demand. Therefore, the article's working hypothesis is that creating and applying new approaches to energy security assessment will allow the timely transformation of the state energy policy in emerging economies. Thus, state energy policy should flexibly respond to changes in global, national, and local environments, supporting sustainable and environmentally friendly energy development.

The remainder of this article is organized as follows. The next part of the Introduction section presents a literature review on national economies' energy security. It identifies problematic aspects of their assessment, considering the RE development and recent global and local challenges for transitive states. The Section 2 describes the research methodology and stages. Section 3 is devoted to improving methodological approaches for assessing the level of emerging economy's energy security based on the example of Ukraine. Using the proposed indicators and the Butterworth band-pass filters, the dynamics of fluctuations in electricity consumption and their impact on the country's energy security are estimated. Section 4 contains conclusions and recommendations for using the results of the study.

\section{Literature Review}

Many scientists devoted their research papers to the energy security issues of national economies: for instance, S. Cox et al. (2019) [24], P. Gasser (2020) [25], E. Hache (2018) [26], I. Kapitula and E. Mischuk (2016) [27], S. Kolosok et al. (2021) [28], B. Lin and M. Raza (2020) [29], M. Pereza et al. (2019) [30], A. Porucnik and K. Kulakovskyi (2017) [31], Y. Samusevych et al. (2021) [32], A. Sutrisno et al. (2021) [33], V. Shkola et al. (2021) [34], etc. Others-for example, V. Dergachova and O. Bedik (2014) [35], I. Doronina (2019) [36], V. Lear (2018) [37], I. Mazur (2014) [38], O. Mykoliuk et al. (2018) [39], L. Sineviciene (2017) [40], O. Sukhodolia (2019) [41], and S. Voitko (2013) [42]—studied the RE deployment and its role in ensuring energy security and sustainable development of the energy sector in transition economies.

Currently, scientists have developed conceptual foundations for the national energy policy formation (for example, $[37,41,43]$ ), proposed the methodological approaches to assessing the country's energy security (in particular, [44-46]), and improved mechanisms to stimulate the RE deployment, aimed at strengthening energy and environmental security of the country (for instance, $[40,47,48]$ ). However, the latest challenges to energy security and RE development related to global (including the COVID-19 pandemic) and local threats have not been studied properly and require further research in their impact on energy security.

For example, P. Gasser [25] analyzes 63 indices quantifying the energy security performance of countries. The author notes that many indicators proposed by researchers lack 
transparency, particularly in the choice of an indicator set, normalization method, indicator weighting scheme, etc. Therefore, the study offers recommendations for improving the methodological framework for assessing energy security.

J.A. Paravantis and N. Kontoulis [45] study the RE impact on energy security and indicate the positive environmental (reduction of $\mathrm{CO}_{2}$ emissions), economic (decline in energy imports), and political and energy (increasing the country's independence from foreign energy suppliers) effects. However, the change of the national energy mix might also be related to risk, which G. Prause et al. [49] highlighted in the case of Estonia. Nevertheless, J.A. Paravantis and N. Kontoulis [45] propose assessing the RE role in strengthening energy security through indicators of physical availability (self-sufficiency and energy diversification); technology development (in particular, onshore and offshore wind farms; diffusion of small-scale and consumer RE systems; research (intensity), development, and innovation in the RE field); social accessibility (electrification and energy democracy, which can be improved through the RE deployment); and natural environment (the reduction of $\mathrm{CO}_{2}$ emissions). Despite the complexity of the proposed approach, it does not consider the latest energy security challenges and RE advancement.

M. Radovanovic et al. [46] propose to measure energy security using the energy security index. The latter takes into account environmental and social aspects along with the security of supply. Index calculations for the four economically strongest EU countries (the United Kingdom, France, Germany, and Italy) over 23 years have proved that increasing the RE share in the energy balance can compensate for the growing demand for imports of fossil fuels and enhance energy security.

D. Fang et al. [44] analyze modern methods of energy security assessment in national economies. They offer a synthetic indicator, "sustainable energy security index", for China, which focuses on the coordinated development of energy, the environment, and the economy. Despite the wide range of sub-indicators included in the calculation, the comprehensive indicator only indirectly considers the impact of RES. However, China is one of the world leaders in green energy development.

E. Hache [26] notes that the transition to RE changes the national energy security priorities. In particular, one should expect structural transformations of national economies, which both import and export fossil fuels due to changes in global demand for traditional energy resources. Dependence on fossil energy will be replaced by dependence on other resources, which will gain strategic importance by developing RE technologies. However, justifying the prerequisites for forming new geopolitics, the author does not offer specific indicators to reflect the considered trends.

In the context of strengthening energy security, T. A. Hamed and L. Bressler [47] note the importance of RE deployment for transitive and developing countries that depend on fossil fuels imports. Using the example of Israel and Jordan, which currently apply feed-in tariffs and auctions for RE projects, the authors analyze RE's potential environmental, political, and economic benefits and suggest new ways to develop the sector. While analyzing sustainable energy security in Iran, S. Solaymani [43] indicates that RE and energy efficiency play positive roles in ensuring sustainable energy development of the country and reducing its economy's carbon intensity despite the sufficient reserves of the state's fossil fuels.

S. L. Cox et al. [24] consider the benefits that RE provides to national energy security. Among them are the diversification of the generation mix, water use reduction, RE modularity and rapid deployment, the possibility of coupling RE with storage, and others. These advantages enable countries and territories to respond quickly and adequately to global and local threats through diversification, decentralization of energy supply and RE storage, and flexible deployment of energy generation systems. S. Kolosok et al. [28] also emphasize the positive RE role in increasing energy security by examining the interaction between green energy and energy efficiency for the EU-28. Instead, analyzing the energy data of 67 economically developed countries, S. Voitko [42] argues that RE does not significantly impact the energy security of economically developed countries. B. Lin and M. Raza [29] 
estimate 11 energy security indicators for long-run energy supply in Pakistan through 2012-2040. According to the researchers, the positive RE impact on energy security in the form of a primary energy supply reduction will occur when the green energy share increases by $28 \%$. However, the authors ignore the latest threats to energy security that the RE advancement may cause.

V. Dergachova and O. Bedik [35] point to a significant decline in the cost of green electricity generation globally in recent years, making the energy market and green energy projects more attractive for investment despite weakening state support. However, one must be aware that RE investments' economic performance still strongly depends on the reference price of fossil fuel, as E.O. Olaniyi and G. Prause [50] pointed out. The authors note that it is necessary to choose a diversified strategy of a country's energy development regarding state energy security without concentrating on any type of energy-either RE or fossil fuels. Instead, O. Mykoliuk et al. [39] emphasize the need for priority RE development to overcome Ukraine's energy dependence and the related economic crisis.

O. Sukhodolia [41] explores new challenges and threats to energy security associated with the proliferation of warfare hybrid methods and energy as a weapon to achieve political goals. He notes that political decisions that run counter to the economic logic of energy development often threaten the energy security of countries with energy shortages. Therefore, the author proposes considering indicators of technically reliable, safe, and cost-effective operation of energy supply systems, energy use efficiency, and environmental acceptability of energy impact when assessing the level of energy security in emerging economies.

Y. Samusevych et al. [32] point to the need to consider the impact of economic and environmental factors on modern energy security. They note that green investments contribute to RE development, which improves environmental quality and national energy security.

V. Lear [37] studies the global transition trends to smart grid technologies and RE development to improve energy security. Using PEST analysis, the author identifies the political, economic, technological, social, and environmental determinants of national energy security, considering such modern types of threats as cyber-attacks, political and armed conflicts, and human-made disasters.

During 2020-2021, many research publications examined the influence of the COVID19 pandemic on the energy industry and countries' energy security-for example [51-53]. Scientists offer scenarios for further development of national energy sectors [54-56] and highlight the RE role in these processes $[55,57,58]$. However, most papers ignore the integral impact of RE, energy fluctuations, and energy efficiency dynamics on the countries' energy security under the COVID-19 pandemic crisis and local threats caused by the new realities for emerging economies.

When assessing energy security, it is necessary to consider the economy's carbon intensity, $\mathrm{CO}_{2}$ emissions in heat and electricity generation processes, energy efficiency, the shares of electricity generated from fossil fuels, alternative and nuclear energy, combustible renewables and waste, etc. A lack of adequate methodological tools for assessing recent challenges and energy security trends reduces the effectiveness of national anti-crisis energy policies in transitive states. Bridging this gap will help implement anti-crisis measures in the energy sector by comprehensively estimating current threats and ensuring energy and environmental sustainability.

Therefore, the research aims to develop a methodology for assessing the energy security level of the emerging economy considering the RE advancement and increasing energy efficiency of production and consumption under the impact of global (including the COVID-19 pandemic) and local threats.

The objectives of the study are as follows:

- To determine the influence of global (including the COVID-19 pandemic) and local threats on the RE deployment and energy efficiency of production and consumption; 
- To develop a methodology for assessing the influence of the RE and energy efficiency dynamics, energy tariffs, and energy fluctuations caused by the COVID-19 pandemic on the energy security level of the transitive economy (in the example of Ukraine);

- To estimate the energy security level of the Ukrainian economy under the energy fluctuations' impact caused by the lockdown of 2020 and provide recommendations for energy policy improvement.

The choice of Ukraine as a study object is due to the following considerations. Currently, this country is actively fostering green energy. Like most emerging and developing states, it faces problems ensuring balanced deployment of RE capacities and assessing their impact on energy security. In addition, lockdowns related to the global COVID-19 pandemic are creating new requirements for the national energy sector, including significant fluctuations in energy demand, its redistribution among consumers, and optimizing the structure of energy capacities. Recent challenges raise the issue of improving approaches to energy security assessment and forecasting. Given the similar problems that other transitive countries face worldwide while developing a green energy sector, recommendations for improving the methodology will be useful for application in Ukraine and far beyond it.

\section{Materials and Methods}

In this study, energy security assessment in the conditions of global and local challenges is performed within three-stage methodology. At the first stage, using comparative analysis, we considered the main impacts of the global COVID-19 crisis on the development of RE and the energy efficiency market. The identification of impacts makes it possible to reveal factors that weaken national energy security.

At the second stage, based on relevant guidelines for calculating Ukraine's economic security level and factors identified at the first stage, the need to involve additional indicators in the methodology for measuring energy security is justified. These indicators reflect the impact of modern challenges on energy security and are based on innovative approaches proposed by the authors.

Overall, we offered five additional indices to include in the assessment of the country's energy security level. Three of them are new: (1) the decoupling index of the renewable energy financial burden on the state budget, (2) the energy efficiency decoupling index, and (3) the indicator of households' energy poverty. The methodology for their calculation is described below in this section. Two indicators from the list (the index of capacity development for balancing the electricity generation volumes in the United Energy System of Ukraine and the indicator of energy fluctuations) are used in energy and economic research but not for estimating energy security within the Ukrainian normative documents. Their application is considered in the Results section.

At the third stage, using economic and mathematical modeling methods, namely, the Butterworth filters, the proposed approach is tested to assess the impact of energy fluctuations in Ukraine's electricity consumption on the country's energy security. The research data includes information about energy consumption by various sectors of the Ukrainian economy, presented on the website of NEC "Ukrenergo" [59]. The study period covers the pre-crisis 2018-2019 and the crisis period of 2020. Based on the analysis of energy fluctuations, appropriate recommendations for energy policy were formed to counter the impact of global and local threats on the energy security of Ukraine.

\subsection{Improving the Methodology for Assessing the Impact of RE on the Energy Security Level}

Ukraine's energy security level is officially determined according to the methodical recommendations for calculating the country's economic security level [14]. Following this document, the integral index includes 10 indicators, namely:

- The share of domestic sources in the fuel and energy balance of the state, $\%$;

- The import dependence on the dominant resource in the total primary energy supply, \%;

- The share of fuel imports from one country (company) in the total import volume, \%;

- Depreciation of fixed assets in energy sector, \%; 
- The ratio of investments in energy enterprises to gross domestic product (GDP), \%;

- Energy intensity of GDP, $\mathrm{kg}$ of oil equivalent/USD;

- Natural gas reserves, months of consumption;

- Stocks of coal, months of consumption;

- The share of RES in the total primary energy supply, \%;

- The share of losses during energy transportation and distribution, $\%$.

Analysis of these indicators points to a need to update and supplement the list because such factors as the RE development, the energy efficiency dynamics, electricity tariffs, and energy fluctuations have become critical in the context of recent global and local threats.

\subsubsection{Impact of RE Development on Energy Security}

Given the recent problems of Ukraine's energy and economic development, in our opinion, the list of indicators that determine the country's energy security level should be supplemented by a relative parameter, which reflects the growing RE financial burden on end-users and the state budget due to the feed-in tariffs' use. This indicator should also consider the countertrend of reducing the RE technologies cost, which creates the preconditions for cutting feed-in tariffs. Therefore, it is proposed to use a modified index of decoupling the RE financial burden on the state budget (Decoupling Index ${ }_{F L}$ ) [60,61], which is calculated as the ratio of the change rate of the weighted average feed-in tariff (EUR/MWh) for all RE technologies used in the country $\left(\Delta I_{F I T}\right)$ to the change rate of the weighted average cost of these RE technologies $\left(\Delta I_{R E c o s t}, E U R / M W h\right)$ :

$$
\text { Decoupling Index }_{F L}=\frac{\Delta I_{F I T}}{\Delta I_{\text {REcost }}} .
$$

The use of the euro to calculate the rates of indicators included in the decoupling index is due to the fixation of the feed-in tariff in Ukraine in euros to avoid the negative impact of fluctuations in the hryvnia exchange rate. This measure protects green electricity producers from inflationary risks and guarantees a stable income from RE-generating capacities.

Decoupling Index $F L$ can be calculated both for all RE technologies on the market and for individual RE technology. In the first case, the indicator will generally show the efficiency/inefficiency of the state pricing policy in the RE market. The second case will demonstrate the efficiency/inefficiency of the state pricing policy for a particular RE technology.

The further away from the unit in modulus is the value of the Decoupling Index $F L$, the more significant the difference (divergence) between the change rate of feed-in tariffs and the change rate of the RE technology cost reduction. It indicates the ineffectiveness of government policy in the field of RE and energy security. The convergence of $\Delta I_{F I T}$ and $\Delta I_{R E c o s t}$ or the decoupling index value close to the unit indicates growing compliance of feed-in tariffs with the RE actual cost. It helps optimize the RE financial burden on the state budget and reduce national energy security threats.

\subsubsection{Impact of Energy Efficiency of Production and Consumption on Energy Security}

Another essential factor determining the countries' energy security and affecting the $\mathrm{RE}$ development is the energy efficiency of production and consumption. Green energy technologies contribute to the growth of national economies' energy efficiency, replacing traditional fossil fuels and decarbonizing economic systems. Thus, it is possible to state the dual connection between energy efficiency and RES and their collective impact on energy security.

Traditionally, the energy efficiency impact is measured by the GDP energy intensity indicator, which for Ukraine is 2-3 times higher than those of the developed countries and neighboring states. Despite the gradual decrease in the energy intensity of the national economy (more than 2.5 times during 1997-2019, according to [62]), Ukraine's GDP energy intensity amounted to $0.232 \mathrm{~kg}$ of oil equivalent/USD (PPP 2015) in 2019. Its value exceeded similar indicators in Poland by 2.73 times ( $0.085 \mathrm{~kg}$ of oil equivalent/USD), Germany by 
3.27 times (0.071 kg of oil equivalent/USD)), and the Czech Republic by 2.15 times $(0.108 \mathrm{~kg}$ of oil equivalent/USD).

The GDP energy intensity, which is part of the energy security indicators in the methodical recommendations, is a cost parameter and does not assess the divergence of energy consumption and economic results concerning the impact on energy security. In modern conditions of fossil fuel depletion, it is insufficient to reduce the GDP energy intensity or increase the energy efficiency of production and consumption. It is essential to minimize the absolute volume of energy resources in economic turnover, thus creating a sustainable development basis. We propose to add energy efficiency decoupling index (Decoupling Index $\left.x_{E E}\right)$, which is calculated as the ratio of the economic growth change rate (GDP, USD) $\left(\Delta I_{G D P}\right)$ to the energy consumption change rate (kg of oil equivalent) $\left(\Delta I_{E C}\right)$ :

$$
\text { Decoupling Index } E E=\frac{\Delta I_{G D P}}{\Delta I_{E C}} \text {. }
$$

This indicator's application allows assessing the dynamic effectiveness of energyefficient measures in the national economy regarding the changes in the economic structure and its impact on energy efficiency and energy security. The further away from the unit in modulus is the value of Decoupling Index $E E$, the greater the divergence between the economic growth and the energy consumption change rates, i.e., the effect of decoupling is observed. The latter can be positive if Decoupling Index $\operatorname{IE}_{E}>1$, while:

1. $\Delta I_{G D P}>\Delta I_{E C}, \Delta I_{G D P}>1$ and $\Delta I_{E C}<1$ means economic growth with declining energy consumption;

2. $\Delta I_{G D P}>1$ and $\Delta I_{\mathrm{EC}}=1$ means economic growth with constant volumes of energy consumption;

3. $\Delta I_{G D P}=1$ and $\Delta I_{\mathrm{EC}}<1$ means energy consumption reduction in the absence of economic growth.

The negative effect of decoupling is observed in other cases in terms of progress in energy efficiency, economic development, or energy security. In the above three points, an increase in production and consumption's energy efficiency is achieved, contributing to energy security strengthening. However, the best option is the first one (economic growth with decreased energy consumption), which ensures the national economy's sustainable development.

\subsubsection{The Impact of Energy Poverty on Energy Security}

Electricity tariffs for consumers are an essential indicator that affects energy security while advancing RE and promoting energy efficiency. On the one hand, tariffs must cover all reasonable costs of energy generators and provide a normal profit to ensure energy security. On the other hand, they should be financially acceptable to consumers. The cost-covering condition is usually met by setting economically reasonable energy prices or subsidizing part of these costs by the state due to social prices. However, the financial burden acceptability requirement is often violated, causing energy poverty. The latter means "the inability to secure a socially and materially necessitated level of energy services in the home" [63] and is traditionally associated with households. To a certain extent, this phenomenon can also be characteristic of non-energy enterprises, particularly small and medium-sized businesses. Due to the increase in energy tariffs, the companies are forced to cut wages and other expenditures to free up funds to pay for energy costs, thereby losing and striving, by all means, to maintain competitive advantages.

The energy poverty level can be estimated as a percentage of households' expenditures for utilities. European and international organizations set this figure at $10 \%$ [64]. For Ukraine, the share of household expenditures on housing, water, electricity, gas, and other fuels was $14.6 \%$ in 2019 , compared to $9.2 \%$ in 2010 and $11.7 \%$ in 2015 . This indicator was below 10\% annually in 2010-2014, while in 2015-2019, it consistently exceeded the 10\% barrier (with a peak value of 17\% in 2017) [65]. Given that purely energy expenditures account for about $80-85 \%$ of household utilities in the last 5 years, it is possible to state 
the Ukrainian population's energy poverty. This type of poverty is closely linked to lowincome households that are unable to pay their utility bills, high energy tariffs, low energy efficiency, and the inability to increase the latter due to low incomes and high energy prices.

Thus, the energy poverty of households significantly affects the state energy and economic security. It is worth including in the list of energy security indicators. The relevant index is calculated by the formula:

$$
k_{u e}=\frac{\operatorname{Exp}_{u t i l}}{I n c_{h h}} \times 100 \%,
$$

where $k_{u e}$ is the households' energy poverty indicator (percentage of households' expenditures for utilities, \%); Exp util is households' energy (utility) expenditures in a certain period, $\mathrm{UAH}$; and $I n c_{h h}$ is the total household income in the same period, UAH.

Exceeding the actual energy poverty threshold of $10 \%$ means an increase in energy and economic insecurity. Fluctuations of the indicator within $10 \%$ demonstrate a satisfactory security level. In addition to energy tariffs, the households' energy poverty index indirectly considers subsidies, the solvency of the population, and the effectiveness of energy-efficient measures in the housing stock.

The above-mentioned indicators (including two indicators considered in the Results section) should be taken into account when calculating the national economy's energy security level regarding the same algorithm used for the existing ten indicators. According to sections IV-VII of the methodical recommendations, this procedure consists of: (1) the formation of an indicators' set; (2) the identification of their characteristic values; (3) their standardization and the weight coefficients calculation; (4) the determination of the integral energy and economic security indices. To summarize, it is an improved methodology for assessing the country's energy security that considers the impact of the RE development, energy efficiency changes, energy price factors, energy fluctuations, and balancing energy capacities.

\section{Results}

3.1. COVID-19 Pandemic Crisis as a Factor Influencing RE Development and Energy Efficiency of the World's and Ukraine's Economies

The COVID-19 pandemic has become a global determinant in developing the world economy in 2020 and has had a significant negative impact on both global and domestic RE markets. Due to quarantine restrictions, key international exhibitions in the RE field (in particular, Cisolar, Energy Transition Europe-Climate Action in London, Berlin Energy Transition, and Solarex Istanbul), through which potential buyers learned about innovative solutions in green energy were canceled [66]. Companies engaged in the equipment production for the RE sector (for example, Siemens Gamesa, Vestas, and Nordex) suffered significant losses, as measures aimed at curbing the COVID-19 pandemic led to disruptions in the production and supply chain of equipment and components for RE facilities [67].

Since the COVID-19 global influence was complex, it affected national green energy industries through different related spheres such as employment, investment, state financial support and price changes, import-export balances, etc. For example, Visegrad countries experienced severe declines in economic activities and instability of financial markets caused by the ongoing pandemic $[68,69]$ that impeded RE deployment.

One of the consequences of the quarantine restrictions caused by the COVID-19 pandemic for the Ukrainian energy market was a decrease in domestic electricity demand. The decline in consumption was observed for most consumer groups, except for the transport sector, agriculture, and the population. Thus, for the 12 months of 2020, electricity consumption amounted to $146,438.9$ million $\mathrm{kWh}$, which is 3798.2 million $\mathrm{kWh}(2.5 \%)$ less than for the corresponding period of 2019 [70]. The decrease in electricity exports brought an additional problem, as quarantine measures had reduced electricity demand in importing countries, namely, Hungary, Romania, Poland, and Belarus. Thus, for the 12 months of 2020, the electricity export amounted to 4754 million $\mathrm{kWh}$, which was $26.5 \%$ 
less than for the 12 months of 2019 [70]. The above necessitated a reduction in electricity generation. Given the priority of RE development, the national government decided not to reduce the green electricity generation but instead limit nuclear generation by shutting down several nuclear power plants' power units. Thus, in 2020, the latter generated $76,202.5$ million $\mathrm{kWh}$ compared to 6800.2 million $\mathrm{kWh}$ in 2019 . The reduction amounted to $8.2 \%$. At the same time, the generation of electricity from RES for 12 months of 2020 amounted to $10,862.1$ million $\mathrm{kWh}$, which is 5319.9 million $\mathrm{kWh}$, or $96 \%$ more than in 2019 [70]. The addition of significant green electricity volumes to the UESU has created two key challenges. The first is associated with an increase in the weighted average electricity price. Since cheap nuclear generation was replaced by expensive electricity from RES, it caused a rise in electricity prices for the population and industry. The second issue refers to balancing the UESU since the addition of significant green electricity volumes requires an increase in flexible capacities, particularly in thermal power plants. It led to the emergence of the so-called "green and coal paradox," when an increase in the volume of electricity from renewables causes a rise in the share of environmentally unfriendly thermal generation in the total energy balance.

Another consequence of the COVID-19 crisis for the Ukrainian energy market was the indefinite delay in the launch of the green auction mechanism, which was supposed to start initially no later than October 2019, then in April 2020, but has not yet started working. This mechanism involves establishing annual governmental quotas to support the RE development for the next 5 years based on the assessment of the conformity (sufficiency) of generating capacities in the UESU [70]. Considering the further RE advancement and its effective integration into the UESU, the mechanism of green auctions is of utmost importance. It helps control the growth of the green energy share in the country's energy mix and regulates the RE structure by prioritizing flexible RE technologies (for example, small hydroelectric power plants). Thus, introducing the green auctions' mechanism will partially solve the green and coal paradox by stimulating the flexible RE capacity deployment while reducing traditional flexible generation's negative environmental impact. In addition to the advantages of power maneuvering, the cost of generating electricity by hydropower is much lower than by solar and wind power, positively affecting the formation of a low weighted average electricity price.

Other consequences of the COVID-19 pandemic impact on the RE market include:

- The reduction of feed-in tariffs (by $7.5 \%$ for wind power plants and $15 \%$ for solar power plants in 2020) is due to the crisis of payments for the feed-in tariff caused by the significant RE share increase in the total energy mix. It is predicted that this measure will provide savings of about 6 billion UAH annually until the end of the installed feed-in tariff period in 2029 [71]. However, it will worsen the investment climate in the RE sector;

- Delay in the supply of equipment and components for the RE facilities construction from China and other countries, which makes it impossible to provide timely commissioning of new RE plants [67];

- Reduction in the number of credit programs for financing green energy projects and a likely increase in interest rates on loans due to the higher risk of investing in the Ukrainian economy during the COVID-19 pandemic [72];

- Potential loss of 20-30\% qualified workers in the labor market, and the outflow of specialists into the working industries, as well as the forced layoff of workers [72,73];

- Suspension of licensing procedures, issuance of permits, and administrative services have reduced business activity in the RE sector during the quarantine period.

Thus, the COVID-19 pandemic significantly affects RE in Ukraine, primarily through the lack of regulation of the green electricity share growth in the total energy mix and the slowing down of all business processes and the banking system's activity in providing new loans.

The situation is similar for the market of energy-efficient goods and services. A slowdown in business activity, delays in the supply of energy-efficient equipment from China, 
uncertainty about the future investments and legal guarantees, a decrease in enterprises' income-all this leads to postponing large-scale energy-efficient projects until better times. Such trends have a negative impact on the development of the domestic energy efficiency market and the dynamics of economic agents' energy efficiency indicators.

In addition to the lack of enterprises' funding for energy efficiency measures and the energy poverty of households, an important reason for the deterioration in the national economy's energy efficiency is the economic crisis caused by the lockdown.

The mentioned trends in the development of green energy and energy efficiency of production and consumption processes negatively affect the Ukrainian economy's energy security. However, it is difficult to quantify their impact due to the imperfection of the current methodology for calculating the energy security level. It does not fully reflect the risks posed by the advancement of RE and energy efficiency, price distortions in the energy market, etc., under the local and global threats. For that reason, it is needed to consider indicators that take into account the capacity of energy balancing between "brown" and "green" energies as well as energy demand fluctuations.

\subsection{The Impact of Energy Balancing on Energy Security}

One of the critical indicators influencing the country's energy security is the UESU's stable operation. The peculiarity of UESU is the excess of basic (nuclear power plants) and the deficit of flexible capacities (thermal, hydro, and hydro-accumulating power plants). Recently, these problems have been exacerbated by the commissioning of a significant number of solar and wind power plants (Table 1).

Table 1. The installed capacity of power-generating facilities in the UESU in 2017-2020.

\begin{tabular}{ccccc}
\hline \multirow{2}{*}{ Energy-Generating Facilities in UESU } & \multicolumn{3}{c}{ Installed Capacity, MW } \\
\cline { 2 - 5 } & $\mathbf{2 0 1 7}$ & $\mathbf{2 0 1 8}$ & $\mathbf{2 0 1 9}$ & $\mathbf{2 0 2 0}$ \\
\hline Nuclear power plants & 13,835 & 13,835 & 13,835 & 13,835 \\
\hline Thermal power plants & 24,565 & 21,842 & 21,842 & 21,842 \\
\hline Combined heat and power (CHP) plants & 5972.3 & 6099.5 & 6097 & 6070 \\
\hline Hydro-and hydro-accumulating power plants & 6228.7 & 6170.2 & 6520 & 6301 \\
\hline Solar power plants & 758.4 & 1388.3 & 4925 & 5154 \\
\hline Wind power plants & 328.4 & 532.8 & 1025 & 1110 \\
\hline Biomass power plants & 96.9 & 97.5 & 170 & 188 \\
\hline Source: [74-77]. & & & &
\end{tabular}

The data in Table 1 show that in 2020, the solar power plants installed capacity growth was 6.8 times greater in comparison with 2017, and wind power plants were 3.4 times greater compared to the same period. The generation of electricity by solar and wind energy facilities is unstable and difficult to predict, as it depends on the time of year, weather patterns, etc. [78-80]. In turn, it requires the commissioning of additional high-flexible capacities, the modernization of power grids, and new methods of accounting for a large number of green energy producers to ensure efficient adding electricity generated from RES to the UESU [80-82].

In recent years, the above problem has intensified and escalated into an energy crisis in 2020. The rapid increase in the RE share in the absence of domestic electricity demand and limited export opportunities due to the COVID-19 quarantine measures and the predominance of basic nuclear generation have created operational safety challenges for the UESU [20]. To ensure the UESU's effective balancing, the government decided to disconnect some power units of Ukrainian nuclear power plants. It resulted in substantial growth of the weighted average cost of electricity and electricity tariffs for final consumers.

The unsustainable operation of the UESU significantly threatens Ukraine's energy security. That is why the indicator of capacity development to balance electricity generation, 
which counts flexible generating facilities and energy storage capacities, should be included in assessing the integrated indicator of energy security.

The index of capacity development for balancing the UESU can be calculated as follows:

$$
\mathrm{I}_{b}=\frac{\sum G P_{m i}+A C}{\sum G C_{i}},
$$

where $I_{b}$ is the capacity development index for balancing the UESU; $G P_{m i}$ is the installed capacity of the $i$-th type of flexible energy-generating facilities, MW; $A C$ is the installed capacity of energy storage facilities, MW; and $G C_{i}$ is the installed capacity of the $i$-th type of energy-generating facilities, MW.

The above index reaches its optimal value at figures close to unity. It ensures the maximum level of energy capacity development for balancing the UESU, which positively affects the country's energy security level.

Today, the UESU balancing should consider the priorities of the national economy's decarbonization. Ukraine is one of the biggest polluters of $\mathrm{CO}_{2}$ due to burning fossil fuels [83]. The energy sector ranks first in terms of emissions among other national economy sectors (about $76 \%$ of total emissions in recent years). Ukraine aims to reduce emissions of carbon dioxide by $40 \%$ compared to 1990 levels by 2030 in the framework of the Paris Climate Agreement [84]. Given this, the UESU balancing with flexible power plants that use fossil fuels is the least appropriate. In addition, the putting into operation of new flexible power plants on fossil fuels is economically ineffective, as today, the cost of electricity production by the most mature RE technologies is already lower than that of brown energy [18].

Deployment of power storage capacity is a promising solution to the problem of balancing the UESU. To date, no energy storage facilities have been introduced in Ukraine; the system operator NEC "Ukrenergo" only plans to implement the first projects with a total installed capacity of $220 \mathrm{MW}$ [85]. In the future, for the extensive deployment of energy storage systems, appropriate state support, particularly the introduction of motivational tools within existing or new mechanisms to intensify the RES advancement, will be needed

In addition to the flexible and energy storage capacities used for balancing the UESU, many other measures can be applied. The main measures are:

1. Connecting the UESU to the European ENTSO-E with permission for import of electricity;

2. Introduction of demand management mechanisms and creation of opportunities for consumers to take an active part in electricity-balancing processes;

3. Deployment of distributed energy facilities based on RES. For example, many geographically spaced small rooftop solar and wind power plants will reduce electricity production unevenness over time and increase the flexibility of power grids [86].

\subsection{Influence of Energy Fluctuations on Energy Security}

To determine the required volumes of the UESU's balancing capacities, it is advisable to monitor the indicator of energy fluctuations, reflecting the peak load on the energy grid and significantly affecting the country's energy security. Smoothing of energy fluctuations provides more stable and reliable functioning of UESU and avoidance of power outages. Forecasting energy fluctuations based on the relevant indicator allows minimizing the risks of maximum peak loads on the grid and timely prevention of emergencies in the UESU. Even though the indicators of capacity development for balancing electricity generation in the UESU and energy fluctuations are interdependent, it is expedient to include them both in the list of energy security indicators. This will help to affect the energy security level by using these two levers simultaneously.

Therefore, the indicator of energy fluctuations can be determined by the formula:

$$
\sum_{t}^{T}\left[\left(x_{t}-\tau_{t}\right)^{2}+\lambda\left(\left(\tau_{t+1}-\tau_{t}\right)+\left(\tau_{t}-\tau_{t-1}\right)\right)^{2}\right],
$$


where $x_{t}$ is the actual value of the electricity consumption/generation in the time period $t$; $\tau_{t}, \tau_{t+1}, \tau_{t-1}$ are trend values of electricity consumption/generation indicator in the time period, respectively, $t,(t+1),(t-1)$; $\lambda$ is the value of the band-pass filter parameter for smoothing fluctuations; and $T$ is the number of studied time periods.

The criterion for evaluating the considered indicator regarding energy security is the range of fluctuations in its values within $20 \%$. This guarantees the optimal mode of energy-generating companies' operation with their energy equipment's economic load when the maximum efficiency of energy equipment use is achieved. Sometimes, short-term operation of units with a load $10-20 \%$ above their nominal capacity at lower efficiency is possible [87]. The mode is called stationary if the power equipment stably operates with the design load at the main parameters' nominal values or when these parameters change within acceptable limits. To ensure the operation of the equipment in stationary mode, we have introduced a permissible range of energy fluctuations of $20 \%$.

Deviation from the trend (fluctuations) $z_{t}=x_{t}-\tau_{t}$ is a cyclical component of business cycles that form the basis of many economic studies. In our case, economic band-pass filters smooth out the trend component and leave high-frequency components from the structure of the economic time series. The smoothing of the second difference of fluctuations occurs due to the parameter $\lambda$. The $\lambda$ value should be established by researchers depending on the time properties of the series. Based on empirical studies, the standard value of the parameter $\lambda$ is 1600 for quarterly data, 6.25-for annual data, and 129,600—for monthly data $[88,89]$.

D. Pollock [90] argues that conventional linear filters (for example, the HodrickPrescott filter) are not flexible enough to be used in real conditions if there are gaps in the upward or downward trends in economic dynamics. These contradictions can be solved by using a rational wave filter known in the physical and mathematical sciences as a digital Butterworth filter. It is more flexible and accurately marks both the frequencies that must remain and those that must be smoothed. Any economic and social indicators are dynamic phenomena with the trend and cyclical components or deviations from the trend with variable volatility and amplitude.

Considering energy security, linear band-pass filters can identify the peak consumption values for individual months of the year while separating the cyclical and trend components. In addition, with the help of the band-pass filters, one can design cycles of electricity consumption for individual groups of consumers. These results will be especially relevant when forecasting renewable electricity generation since the latter is cyclical.

Tracking and predicting the fluctuations could help regulate energy production and consumption and prevent energy crises and economic and environmental damage. Based on the identified fluctuations, it is possible to assess the RE development, energy production and consumption efficiency, and their impact on state energy security dynamics.

To identify the nature of changes in energy consumption of Ukraine's businesses and the population in the crisis of 2020, we studied the dynamics of electricity consumption in 2018-2020. The COVID-19 crisis has transformed the electricity demand. That is why the previous 2 "conditionally prosperous" years were taken for comparison.

Using Ukraine's monthly electricity consumption data and methodological approaches involving the Butterworth filter [91,92], we considered the energy fluctuations. Figure 1 presents the Coronavirus and quarantine restrictions' impact on the energy consumption cyclical components in Ukraine.

Figure 1 demonstrates that the volatility of electricity consumption in Ukraine in 2018 was slightly higher than in 2020, where there were minimal deviations from the trend component. As for the structure of net electricity consumption cycles in Ukraine for all consumer groups, the Coronavirus crisis and the introduction of quarantine measures did not affect the cyclical component, except for a decrease in the depth of fluctuations in 2020. 


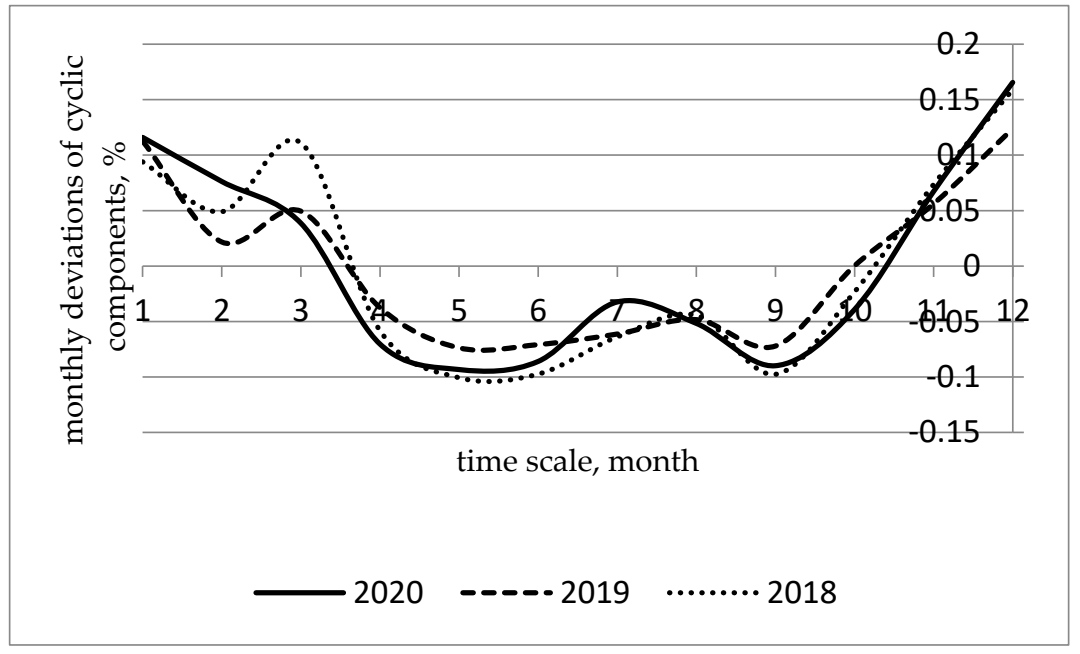

Figure 1. Fluctuations of net electricity consumption in Ukraine in 2018-2020 by all consumer groups (compiled by the authors based on the data [59]).

Short-term deviations from the trend caused by an insignificant shock can be reflected in a leading and converging series of economic dynamics. Based on this, incorrect conclusions can be drawn about the existence of a systemic process in the economic cycle structure. Let us analyze the COVID-19 and quarantine restrictions' influence on the cyclical components of electricity consumption by the household sector of Ukraine (Figure 2).

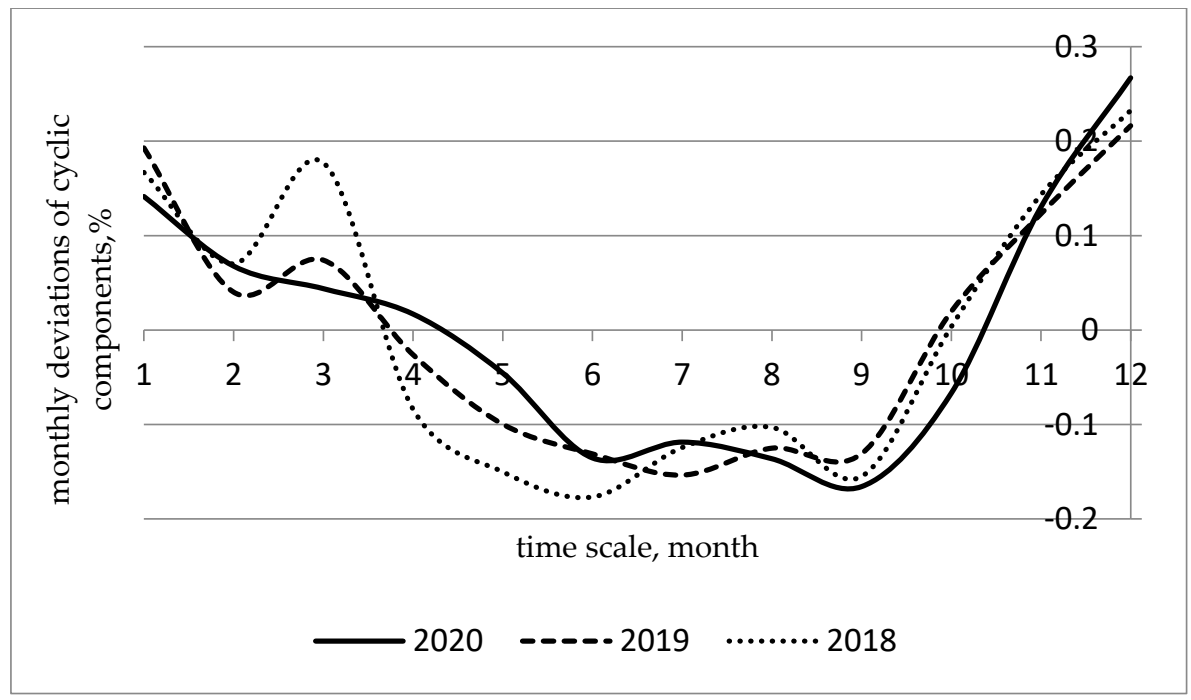

Figure 2. Electricity consumption fluctuations in the household sector of Ukraine in 2018-2020 for all consumer groups (compiled by the authors based on the data [59]).

Figure 2 demonstrates that the volatility of fluctuations in 2020 was almost the same as in the pre-crisis period. However, the quarantine measures strengthening at the end of 2020 caused an increase in the fluctuations of electricity consumption by the population of Ukraine above $25 \%$. It was more than $5 \%$ higher than the optimal criterion level of electricity consumption fluctuations. It was due to lower seasonal temperatures and quarantine measures forcing households to consume more electricity at home. Exceeding the permissible level by $5 \%$ did not become critical for the UESU, as this phenomenon turned out to be short-lived, and energy-generating companies had sufficient technological reserves to cover this energy need.

However, the electricity consumption divergence in 2020 and previous periods is interesting to consider. The government announced quarantine measures in March 2020. 
Consequently, the population's electricity consumption has declined somewhat. However, the previous periods demonstrated increasing energy consumption at the end of March. Two years earlier (2018-2019), June and September showed the cyclical electricity consumption minimum with further growth. In 2020, the cyclical minimum did not differ from the previous periods.

Let us analyze the cyclical component of electricity consumption by the industrial enterprises of Ukraine (Figure 3).

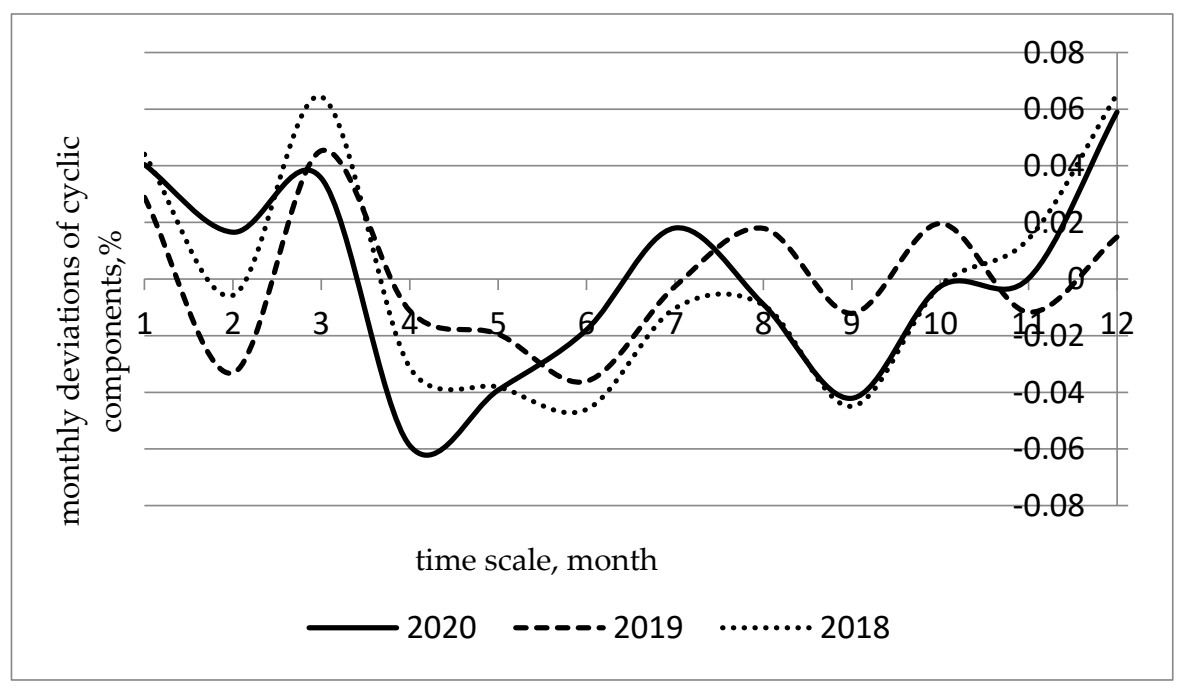

Figure 3. Fluctuations in electricity consumption by industrial enterprises of Ukraine for all consumer groups in 2018-2020 (compiled by the authors based on the data [59]).

Figure 3 indicates that Ukraine's industrial enterprises did not show their usual maximum cyclical electricity consumption in March 2020. By contrast, April-May 2020 demonstrated minimal cyclical values of electricity consumption due to quarantine restrictions. Additionally, Figure 3 shows that the cyclical component of the electricity consumption in the industry in 2020 was different from 2018 to 2019.

To sum up, the COVID-19 crisis has changed the electricity consumption patterns of all consumer groups. The pandemic made energy enterprises adjust their work mode to the new energy demand peaks in terms of energy security. Each COVID-19 wave is projected to raise household electricity consumption and reduce the energy load of industrial enterprises.

Considering forecasting the impact of RE development and energy efficiency of production and consumption on the country's energy security based on fluctuations, the COVID-19 crisis did not cause technological problems for power generating companies as consumption fluctuations were lower than in the pre-crisis years. The equalization of electricity consumption across all consumer groups due to the COVID-19 crisis has not negatively affected the level of energy security except for balancing different types of energy capacities in the UESU. However, the likelihood of illness among power generating companies' staff may cause disruptions in energy and economic systems' operation. Therefore, power-generating enterprises should implement smart-grid technologies to improve the country's energy security.

Besides, in the further anti-crisis management of the energy sector, it is expedient to consider the recent trends of the electricity generation redistribution in favor of an increase in the renewable energy share. In addition, because of the COVID-19 pandemic, investment in energy-efficient capacities will decrease while worsening the energy, environmental, and economic security of Ukraine. Therefore, the government should adequately respond to these challenges. 


\section{Conclusions}

In 2020, the COVID-19 pandemic significantly changed Ukraine's economic development priorities, exacerbating energy security issues and forcing the government to reconsider the range of factors that affect it. High feed-in tariffs and a state guarantee to purchase $100 \%$ of green energy have turned RE development drivers into a threat to the country's energy security due to the unbearable financial burden on the state budget. Reducing investment in energy-efficient projects, increasing energy poverty of households, changes in energy fluctuations, and exacerbating issues of balancing energy capacities in the UESU are the current constraints on energy generation and consumption in Ukraine's economy.

Therefore, it is necessary to develop a methodology for assessing the energy security level of the national economy considering the RE advancement and increasing energy efficiency of production and consumption under the above threats. To this end, we have substantiated proposals to supplement the normative list of energy security indicators with five more indices, namely, by the decoupling index of the RE financial burden on the state budget, the energy efficiency decoupling index, the indicator of households' energy poverty, the index of capacity development for balancing electricity generation in the UESU, and the indicator of energy fluctuations. The proposed indicators consider the latest security challenges of the national economy. On their basis, it is easier to justify and implement anti-crisis management decisions while responding in a timely and adequate manner to global and local threats.

Along with assessing and tracking the energy security level, it is essential to predict its change based on the volatility of electricity generation and consumption. It is found that energy fluctuations within the range of $20 \%$ guarantee energy security and optimal mode of energy-generating companies' operation when the maximum efficiency of energy equipment use is achieved. In particular, the larger the amplitude gaps are, the more unpredictable the level of electricity consumption is. These research results can be used to forecast changes in the energy and economic security of the emerging economy by analyzing the volatility and amplitude of fluctuations in electricity consumption.

A slowdown in business activity, delays in the supply of energy-efficient equipment from China, uncertainty about the future investments and legal guarantees, a decrease in enterprises' income-all this leads to postponing large-scale, energy-efficient projects until better times. Considering energy security, linear band-pass filters can identify the peak consumption values for individual months of the year while separating the cyclical and trend components.

When it comes to forecasting energy needs, the COVID-19 crisis is changing the energy consumption patterns. Therefore, energy-generating companies should pay more attention to households' needs since they will create peak loads. Moreover, there is a possibility that grid congestion may occur in household consumers with an increase in the number of economic lockdowns. To ensure energy and economic security, it is necessary to smooth out fluctuations in energy consumption through RE development, the formation of smart grids, energy efficiency improvements, and energy capacities balancing, which are directions for further research in this area. The implementation of these opportunities will ensure the national economies' decarbonization and the achievement of other goals for the states' sustainable development.

The proposed methodological approaches to improving energy security assessment can be used by public authorities that regulate the RE sector in Ukraine to correct the state energy policy taking into account recent challenges. Such authorities are the Ministry of Energy of Ukraine, the State Agency for Energy Efficiency and Energy Saving, and the National Commission for State Regulation of Energy and Public Utilities. In addition, the proposed methodological approaches can be used as a basis for improving the legislation in the RE development field in other emerging countries, which face similar problems.

The limitations of the research are related to the fact that the proposed ratios and indexes are tested based only on one country. The further direction of the study should be focused on making an international comparison of energy security assessment in the 
conditions of global and local challenges. Additionally, stochastic modeling approaches should be developed to build empirical econometric models for energy security assessment.

Author Contributions: I.S. and T.K. conceptualized and prepared the methodology for the project; O.K., G.T. and U.P. provided the software and validation; G.T. performed the formal analysis; U.P. performed the research; Y.K, O.P. and I.S. guaranteed the resources and data curation; I.S. and T.K. wrote the original version of the text; I.S., O.P., G.P. and Y.K. participated in the writing of the article, namely, by reviewing and editing the text; I.S., O.P. and O.K. provided supervision and visualization of the project; O.P. and Y.K. were responsible for project administration; I.S., G.P. and Y.K. secured the funding. All authors have read and agreed to the published version of the manuscript.

Funding: This research was funded by the National Research Foundation of Ukraine in the framework of the research project "Formation of economic mechanisms for sustainable development of renewable energy in the conditions of global and local threats to energy security of Ukraine" (No. 0120U104806).

Institutional Review Board Statement: Not applicable.

Informed Consent Statement: Not applicable.

Data Availability Statement: This study analyzed publicly available datasets. The data can be found here: http:/ / www.ukrstat.gov.ua/; https:/ / ua.energy (accessed on 11 September 2021).

Conflicts of Interest: The authors declare no conflict of interest. The funders had no role in the design of the study; in the collection, analyses, or interpretation of data; in the writing of the manuscript, or in the decision to publish the results.

\section{References}

1. UN. Take Action for the Sustainable Development Goals. Available online: https://www.un.org/sustainabledevelopment/ sustainable-development-goals / (accessed on 11 December 2020).

2. Prokopenko, O.; Chechel, A.; Sotnyk, I.; Omelyanenko, V.; Kurbatova, T.; Nych, T. Improving state support schemes for the sustainable development of renewable energy in Ukraine. Polityka Energetyczna 2021, 24, 85-100. [CrossRef]

3. Melnyk, L.; Sommer, H.; Kubatko, O.; Rabe, M.; Fedyna, S. The economic and social drivers of renewable energy development in OECD countries. Probl. Perspect. Manag. 2020, 18, 37-48. [CrossRef]

4. Prokopenko, O.; Cebula, J.; Chayen, S.; Pimonenko, T. Wind energy in Israel, Poland and Ukraine: Features and opportunities. Intern. J. Ecol. Dev. 2017, 32, 98-107.

5. Us, Y.; Pimonenko, T.; Lyulyov, O. Energy efficiency profiles in developing the free-carbon economy: On the example of Ukraine and the V4 countries. Polityka Energetyczna 2021, 23, 49-66. [CrossRef]

6. Bilan, Y.; Streimikiene, D.; Vasylieva, T.; Lyulyov, O.; Pimonenko, T.; Pavlyk, A. Linking between renewable energy, $\mathrm{CO}_{2}$ emissions, and economic growth: Challenges for candidates and potential candidates for the EU membership. Sustainability 2019, 11, 1528. [CrossRef]

7. Lyeonov, S.; Pimonenko, T.; Bilan, Y.; Štreimikiene, D.; Mentel, G. Assessment of green investments' impact on sustainable development: Linking gross domestic product per capita, greenhouse gas emissions and renewable energy. Energies 2019, 12, 3891. [CrossRef]

8. Pimonenko, T.; Prokopenko, O.; Dado, J. Net zero house: EU experience in Ukrainian conditions. Int. J. Ecol. Econ. Stat. 2017, $38,46-57$.

9. WEC. World Energy Trilemma Index. Available online: https://www.worldenergy.org/transition-toolkit/world-energytrilemma-index (accessed on 17 February 2021).

10. Kurbatova, T.; Sotnyk, I.; Kubatko, O.; Baranchenko, Y.; Arakpogun, E.; Roubik, H. State support policy for renewable energy development in emerging economies: The case of Ukraine. Int. J. Glob. Environ. Issues 2020, 19, 26-52. [CrossRef]

11. Kurbatova, T.; Perederii, T. Global trends in renewable energy development. In Proceedings of the 2020 IEEE KhPI Week on Advanced Technology (KhPIWeek), Kharkiv, Ukraine, 5-10 October 2020; pp. 260-263. [CrossRef]

12. UA News. Energy Crisis: Why Nuclear Power Units Are Shut Down in Ukraine. Available online: https://ua.news/ua/kryzysenergetyky-pochemu-v-ukrayne-otklyuchayut-atomnye-energobloky/ (accessed on 17 February 2021).

13. SE "Energorynok". Price Analysis in UME. Available online: http:/ /www.er.gov.ua/doc.php?c=5 (accessed on 17 February 2021).

14. Methodical Recommendations for Calculating the Level of Economic Security of Ukraine: Approved by the Order of the Ministry of Economic Development and Trade of Ukraine No. 1277 from 29.10.2013. Available online: https://zakon.rada.gov.ua/rada/ show/v1277731--13\#Text (accessed on 17 February 2021).

15. Explanatory Note to the Draft Law of Ukraine “On amendments to Certain Legislative Acts of Ukraine Concerning the Conditions of Sustainable Operation of a Guaranteed Buyer". Available online: http://search.ligazakon.ua/1_doc2.nsf/link1/GI04456A.html (accessed on 17 February 2021). 
16. Feed-in Tariff for Home Solar Panels Can Be Cut Three Times. Available online: https://www.unian.net/economics/energetics/ 10597200-zelenyy-tarif-dlya-domashnih-solnechnyh-paneley-mogut-sokratit-v-tri-raza.html (accessed on 10 July 2019 ).

17. The Renewable Energy Share at the Market Increased to $8 \%$, which is $26 \%$ of the Money Supply-NEURC. Available online: https:/ / www.unian.ua/economics/energetics / chastka-vidnovlyuvanoji-energetiki-na-rinku-zrosla-do-8-shcho-stanovit26-groshovogo-obigu-nkrekp-novini-sogodni-10984802.html (accessed on 17 February 2021).

18. Renewable Power Generation Costs in 2019. Available online: https://www.irena.org/-/media/Files/IRENA/Agency/ Publication/2020/Jun/IRENA_Power_Generation_Costs_2019.pdf (accessed on 17 February 2021).

19. On Electricity Market: Law of Ukraine 2019_VIII from 01.01.2021. Available online: https://zakon.rada.gov.ua/laws/show/20 19--19\#Text (accessed on 17 February 2021).

20. Katser, Y.; Kulinich, V. Coronavirus vs Energy: Why Green Auctions Don't Work. Available online: https:/ / mind.ua/openmind/ 20208551-koronavirus-vs-energetika-chomu-ne-pracyuyut-zeleni-aukcioni (accessed on 17 February 2021).

21. Niftiyev, I. How to Conceptualize the Resource Curse and Dutch Disease Theories in the Case of Azerbaijan? Initial and Negative Findings. Working Paper No. 5. 2021. Available online: https:/ / papers.ssrn.com/sol3/papers.cfm?abstract_id=3857936 (accessed on 9 September 2021).

22. Sadik-Zada, E.R.; Loewenstein, W.; Hasanli, Y. Production linkages and dynamic fiscal employment effects of the extractive industries: Input-output and nonlinear ARDL analyses of Azerbaijani economy. Miner Econ. 2021, 34, 3-18. [CrossRef]

23. Sadik-Zada, E.R. Addressing the growth and employment effects of the extractive industries: White and black box illustrations from Kazakhstan. Post-Communist Econ. 2021, 33, 402-434. [CrossRef]

24. Cox, S.L.; Beshilas, L.; Hotchkiss, E.L. Renewable Energy to Support Energy Security. NREL/TP-6A20-74617; 2019. Available online: https: / / www.nrel.gov/docs/ fy20osti/74617.pdf (accessed on 9 September 2021).

25. Gasser, P. A review on energy security indices to compare country performances. Energy Policy 2020, 139, 111339. [CrossRef]

26. Hache, E. Do renewable energies improve energy security in the long run? Int. Econ. 2018, 156, 127-135. [CrossRef]

27. Kapitula, I.; Mischuk, E. Methodical approaches to the assessment of energy security as a component of economic security of the national economy of Ukraine in modern conditions of transformation of the economy. Black Sea Econ. Stud. 2016, 7, 51-54. Available online: http://nbuv.gov.ua/UJRN/bses_2016_7_11 (accessed on 17 February 2021).

28. Kolosok, S.; Myroshnychenko, I.; Mishenina, H.; Yarova, I. Renewable energy innovation in Europe: Energy efficiency analysis. ICIES 2020. E3S Web Conf. 2021, 234, 00021. [CrossRef]

29. Lin, B.; Raza, M. Analysis of energy security indicators and $\mathrm{CO}_{2}$ emissions. A case from a developing economy. Energy 2020, 200, 117575. [CrossRef]

30. Pereza, M.; Scholten, D.; Stegen, K. The multi-speed energy transition in Europe: Opportunities and challenges for EU energy security. Energy Strategy Rev. 2019, 26, 100415. [CrossRef]

31. Porucnik, A.; Kulakovskyi, K. Energy security and diversification of energy resources. Ekon. Derzhava 2017, 8, 18-21. Available online: http:/ / www.economy.in.ua/pdf/8_2017/7.pdf (accessed on 17 February 2021).

32. Samusevych, Y.; Vysochyna, A.; Vasylieva, T.; Lyeonov, S.; Pokhylko, S. Environmental, energy and economic security: Assessment and interaction. ICIES 2020. E3S Web Conf. 2021, 234, 00012. [CrossRef]

33. Sutrisno, A.; Nomaler, O.; Alkemade, F. Has the global expansion of energy markets truly improved energy security? Energy Policy 2021, 148, 111931. [CrossRef]

34. Shkola, V.; Prokopenko, O.; Stoyka, A.; Nersesov, V.; Sapiński, A. Green Project Assessment within the Advanced Innovative Development Concept. Estud. Econ. Apl. 2021, 39. [CrossRef]

35. Dergachova, V.; Bedik, O. Emergence renewable energy in Ukraine as a component of the state economic security. Econ. Bull. NTUU "KPI" 2014, 11, 133-137. Available online: https:/ / ela.kpi.ua/bitstream/123456789/11360/1/23.pdf (accessed on 17 February 2021).

36. Doronina, I. Mechanisms of state regulation of renewable energy development: World trends and Ukrainian realities. Bull. NAPA Ser. Pub. Admin. 2019, 4, 25-32. Available online: http://visnyk.academy.gov.ua/pages/dop/87/files/a0dd7b5a-b751--4a37--9 c56-dfb328802c7f.pdf (accessed on 17 February 2021).

37. Lear, V. Imperatives and Determinants of Energy Policy of Sustainable Development; Institute of Economics and Forecasting of the National Academy of Science of Ukraine: Kyiv, Ukraine, 2018.

38. Mazur, I. Criteria for assessing energy security: A resource approach. Act. Probl. Reg. Econ. Develop. 2014, 10, 148-156. Available online: http:/ / nbuv.gov.ua/UJRN/aprer_2014_10_25 (accessed on 17 February 2021).

39. Mykoliuk, O.; Zhelavska, I.; Liakhovets, V. Formation of key vectors to ensure energy safety creation of the prize of development of alternative energy. Bull. Khmelnytsk. Nation Univ. Econ. Sci. 2018, 3, 199-204. Available online: http://elar.khnu.km.ua/jspui/ bitstream/123456789/6698/1/13.pdf (accessed on 17 February 2021).

40. Sineviciene, L.; Sotnyk, I.; Kubatko, O. Determinants of energy efficiency and energy consumption of Eastern Europe postcommunist economies. Energy Environ. 2017, 28, 870-884. [CrossRef]

41. Sukhodolia, O. The problems of defining the scope of energy security regulation. Strateg. Prior. 2019, 1, 5-17. Available online: https://niss-priority.com/index.php/journal/article/view/233/221 (accessed on 17 February 2021).

42. Voitko, S. System analysis of energy security: The aspect of using renewable energy. Econ. Forum 2013, 4, 29-35. Available online: http:/ / nbuv.gov.ua/UJRN/ecfor_2013_4_8 (accessed on 17 February 2021).

43. Solaymani, S. A demand-side assessment of sustainable energy security in Iran. IJEWR 2020, 4, 307-320. [CrossRef] 
44. Fang, D.; Shi, S.; Yu, Q. Evaluation of sustainable energy security and an empirical analysis of China. Sustainability 2018, 10, 1685. [CrossRef]

45. Paravantis, J.A.; Kontoulis, N. Energy Security and Renewable Energy: A Geopolitical Perspective. In Renewable Energy-Resources, Challenges and Applications; Al Qubeissi, M., Ed.; Intech Open: London, UK, 2020. [CrossRef]

46. Radovanovic, M.; Filipovic, S.; Pavlovic, D. Energy security measurement-A sustainable approach. Renew. Sustain. Energy Rev. 2017, 68, 1020-1032. [CrossRef]

47. Hamed, T.A.; Bressler, L. Energy security in Israel and Jordan: The role of renewable energy sources. Renew. Energy 2019, 135, 378-389. [CrossRef]

48. Sotnyk, I.; Kurbatova, T.; Dashkin, V.; Kovalenko, Y. Green energy projects in households and its financial support in Ukraine. Int. J. Sustain. 2020, 39, 218-239. [CrossRef]

49. Prause, G.; Tuisk, T.; Olaniyi, E.O. Between sustainability, social cohesion and security. Regional development in North-Eastern Estonia. Entrep. Sustain. Issues 2019, 6, 1235-1254. [CrossRef]

50. Olaniyi, E.O.; Prause, G. Investment analysis of waste heat recovery system installations on ships' engines. J. Mar. Sci. Eng. 2020 8, 811. [CrossRef]

51. Brosemer, K.; Schelly, C.; Gagnon, V.; Arola, K.L.; Pearce, J.M.; Bessette, D.; Schmitt Olabisih, L. The energy crises revealed by COVID: Intersections of Indigeneity, inequity, and health. ERSS 2020, 68, 101661. [CrossRef] [PubMed]

52. Covid-19 Impact on Electricity; IEA: Paris, France, 2021; Available online: https://www.iea.org/reports/covid-19-impact-onelectricity (accessed on 17 February 2021).

53. Jiang, P.; Fan, Y.V.; Klemes, J.J. Impacts of COVID-19 on energy demand and consumption: Challenges, lessons and emerging opportunities. Appl. Energy 2021, 285, 116441. [CrossRef]

54. Heffron, R.J.; Körner, M.-F.; Schöpf, M.; Wagner, J.; Weibelzahl, M. The role of flexibility in the light of the COVID-19 pandemic and beyond: Contributing to a sustainable and resilient energy future in Europe. Renew. Sustain. Energy Rev. 2021, 40, 110743. [CrossRef]

55. The Post-COVID Recovery: An Agenda for Resilience, Development and Equality; IRENA: Abu Dhabi, United Arab Emirates, 2020; ISBN 978-92-9260-245-1.

56. Laveron, F. The role of the electricity sector in the energy transition after COVID-19. Forum 2020, 123, 38-41. Available online: https:/ / www.oxfordenergy.org/wpcms/wp-content/uploads/2020/07/OEF123.pdf (accessed on 17 February 2021).

57. Chiaramonti, D.; Maniatis, K. Security of supply, strategics to rage and Covid-19: Which lessons learnt for renewable and recycled carbon fuels, and their future role in decarbonizing transport? Appl. Energy 2020, 271, 115216. [CrossRef]

58. COVID-19 and the Low-Carbon Transition. Impacts and Possible Policy Responses. Available online: https://read.oecd-ilibrary. org /view / ?ref=134_134752-qmhlk04mue\&title=COVID\%E2\%80\%9319-and-the-low-carbon-transition-Impacts-and-possiblepolicy-responses (accessed on 17 February 2021).

59. NEC “Ukrenergo". Energy Consumption. Available online: https://ua.energy/peredacha-i-dyspetcheryzatsiya/dyspetcherskainformatsiya/elektrospozhyvannya/ (accessed on 17 February 2021).

60. OECD Report: SG/SD(2002)1/Final. 4. Indicators to Measure Decoupling of Environmental Pressure from Economic Growth. Available online: http://search.oecd.org/officialdocuments / displaydocumentpdf/?doclanguage $=\mathrm{en} \& \operatorname{cote}=\mathrm{sg} / \mathrm{sd}(2002) 1 / \mathrm{final}$ (accessed on 17 February 2021).

61. Sotnyk, I.; Kulyk, L. Decoupling analysis of economic growth and environmental impact in the regions of Ukraine. Econ. Ann. XXI 2014, 7-8, 60-64. Available online: http:/ / soskin.info/ea/2014/7--8/201450.html (accessed on 17 February 2021).

62. Global Energy Statistical Yearbook. Energy Intensity. 2020. Available online: https://yearbook.enerdata.net/total-energy/worldenergy-intensity-gdp-data.html (accessed on 17 February 2021).

63. Bouzarovski, S.; Tirado Herrero, S. The energy divide: Integrating energy transitions, regional inequalities and poverty trends in the European Union. Eur. Urban Reg. Stud. 2017, 24, 69-86. [CrossRef]

64. What Caused the Energy Poverty of Ukrainian Households, 25 September 2014. Available online: https://ecotown.com.ua/ news/CHym-sprychynena-enerhetychna-bidnist-ukrayinskykh-domohospodarstv/ (accessed on 17 February 2021).

65. State Statistics Service of Ukraine. Expenditures and Resources of Households in Ukraine (According to a Sample Survey of Households' Living Conditions). Available online: http:/ / www.ukrstat.gov.ua/ (accessed on 17 February 2021).

66. Werth, A.; Gravino, P.; Prevedello, G. Impact analysis of COVID-19 responses on energy grid dynamics in Europe. Appl. Energy 2021, 281, 116045. [CrossRef] [PubMed]

67. Kosatka Media. Coronavirus Continues to Affect the Wind Sector, German Nordex Rejects Financial Forecasts. Available online: https:/ / kosatka.media/uk/category/vozobnovlyaemaya-energia/news / koronavirus-prodolzhaet-vliyat-na-sektorves-nemeckiy-nordex-otkazyvaetsya-ot-finansovyh-prognozov (accessed on 17 February 2021).

68. Niftiyev, I.; Huseynova, R. How has the self-perceived health shaped the Covid-19 causalities in the Visegrad countries? In Proceedings of the 3th International Scientific and Practical Conference "Theory and Practice of Science: Key Aspects", Rome, Italy, 21-22 May 2021; Volume 58, pp. 60-71. [CrossRef]

69. Czech, K.; Wielechowski, M.; Kotyza, P.; Benešová, I.; Laputková, A. Shaking stability: COVID-19 impact on the Visegrad Group countries' financial markets. Sustainability 2020, 12, 6282. [CrossRef] 
70. Information on the Operation of the Power Complex for December 2020-Operational Data. Ministry of Energy of Ukraine, 2021. Available online: http:/ / mpe.kmu.gov.ua/minugol/control/uk/publish/article?art_id=245505335\&cat_id=245183225 (accessed on 17 February 2021).

71. The President Signed a Law on Improving the Conditions for Supporting Feed-In Tariff Energy: Major Changes. Available online: https: / / www.kmu.gov.ua/news/prezident-pidpisav-zakon-pro-vdoskonalennya-umov-pidtrimki-zelenoyi-energetikiyaki-zmini-vin-peredbachaye (accessed on 17 February 2021).

72. Impact of Coronavirus on the Renewable Energy Sector: Ukrainian Context. Kosatka.Media, 2020. Available online: https:// kosatka.media/en/category/blog/news/vliyanie-koronavirusa-na-sektor-vozobnovlyaemoy-energetiki-ukrainskiy-kontekst (accessed on 17 February 2021).

73. How is the Ukrainian Solar Business Experiencing a Crisis? Available online: https://getmarket.com.ua/ua/news/yak-ukrayinskij-sonyachnij-biznes-perezhivaye-krizu (accessed on 17 February 2021).

74. National Commission for State Regulation of Energy and Public Utilities Report on the Activity Results in Ukraine in 2017. Available online: http://www.nerc.gov.ua/index.php/data/filearch/Materialy_zasidan/data/filearch/Catalog3/Richnyi_zvit_ NKREKP_2017.pdf (accessed on 17 February 2021).

75. National Commission for State Regulation of Energy and Public Utilities Report on the Activity Results in Ukraine in 2018. Available online: http:/ / www.nerc.gov.ua/index.php/data/filearch/Proekty/2018/data/?id=39678 (accessed on 17 February 2021).

76. National Commission for State Regulation of Energy and Public Utilities Report on the Activity Results in Ukraine in 2019. Available online: http:/ / www.nerc.gov.ua/index.php/map_1/data/filearch/Proekty/data/filearch/Catalog3/Richnyi_zvit_ NKREKP_2019.pdf (accessed on 17 February 2021).

77. NEC “Ukrenergo". The Capacity of the Energy System of Ukraine as of the End of 2020. Available online: https: / ua.energy / vstanovlena-potuzhnist-energosystemy-ukrayiny / (accessed on 17 February 2021).

78. Hassan, M.Z.; Ali, M.E.K.; Ali, A.B.M.S.; Kumar, J. Forecasting day-ahead solar radiation using machine learning approach. In Proceedings of the 2017 th Asia-Pacific World Congress on Computer Science and Engineering (APWC on CSE), Mana Island, Fiji, 11-13 December 2017; pp. 252-258. [CrossRef]

79. Sanjari, M.J.; Gooi, H.B.; Nair, N.-C. Power generation forecast of hybrid PV-wind system. IEEE Trans. Sustain. Energy 2020, 11, 703-712. [CrossRef]

80. Groppi, D.; Pfeifer, A.; Garcia, D.A.; Krajačić, G.; Duić, N. A review on energy storage and demand side management solutions in smart energy islands. Renew. Sustain. Energy Rev. 2021, 135, 110183. [CrossRef]

81. Skibina, T.; Kurbatova, T.; Sotnyk, I.; Telizhenko, O.; Sotnyk, M.; Hyrchenko, Y. Estimation of management efficiency of energy supply companies in emerging economies. TEM J. 2021, 10, 238-248. [CrossRef]

82. Borowski, P.F. Digitization, Digital Twins, Blockchain, and Industry 4.0 as Elements of Management Process in Enterprises in the Energy Sector. Energies 2021, 14, 1885. [CrossRef]

83. Olivier, J.G.J.; Peters, J.A.H.W. Trends in Global $\mathrm{CO}_{2}$ and Total Greenhouse Gas Emissions: 2019 Report; PBL Netherlands Environmental Assessment Agency: Hague, The Netherlands, 2020; Available online: https:/ /www.pbl.nl/sites/default/files/downloads/pbl2020-trends-in-global-co2-and-total-greenhouse-gas-emissions-2019-report_4068.pdf (accessed on 17 February 2021).

84. EP: Paris Climate Agreement: Ukraine Needs to Reduce Emissions by 70\%. Available online: https://www.epravda.com.ua/ publications /2016/03/18/585855/ (accessed on 17 February 2021).

85. NEC "Ukrenergo". The EBRD and IFC Will Start Implementing Projects to Build an Energy Storage System in Ukraine. Available online: https: / / ua.energy/zagalni-novyny/ukrenergo-yebrr-ta-ifc-rozpochnut-realizatsiyu-proektiv-shhodo-rozbudovy-vukrayini-systemy-energy-storage/ (accessed on 17 February 2021).

86. Gritsishina, M. Energy Balance: What is Needed to Create Balancing Capacities in Ukraine. Available online: https://mind.ua/ openmind/20202701-energetichna-rivnovaga-shcho-treba-dlya-stvorennya-balansuyuchih-potuzhnostej-v-ukrayini (accessed on 17 February 2021).

87. Energetics. Book 3. Development of Heat and Hydropower. Available online: http://energetika.in.ua/ru/books/book-3/part-1/ section-1/1--2 (accessed on 17 February 2021).

88. Ravn, M.O.; Uhlig, H. On adjusting the Hodrick-Prescott filter for the frequency of observations. Rev. Econ. Stat. 2002, 84, 371-376. [CrossRef]

89. Rebelo, S. Real Business Cycle Models: Past, Present, and Future; NBER Working Papers: Cambridge, MA, USA, $2005 ;$ p. 11401. [CrossRef]

90. Pollock, D.S.G. Trend estimation and detrending via rational square wave filters. J. Econom. 2000, 99, 317-334. [CrossRef]

91. Kubatko, O. Synchronization and uniformity assessment of economic and environmental fluctuations. J. Zhytomyr State Technol. Univ. Econ. Ser. 2017, 2, 92-97.

92. Kubatko, O. Fluctuations and cycles in the series of ecological and economic dynamics. Econ. Soc. 2017, 9, 837-844. Available online: https: / / economyandsociety.in.ua/journals/9_ukr/146.pdf (accessed on 17 February 2021). 